\title{
EVALUASI KOMBINASI ISOLAT TRICHODERMA MIKOPARASIT DALAM MENGENDALIKAN PENYAKIT AKAR PUTIH PADA BIBIT KARET
}

\author{
Suwandi ${ }^{1}$
}

\begin{abstract}
Evaluation of mycoparasitic Trichoderma isolate mixtures to control white root disease on rubber seedlings. Eight isolates of mycoparasitic Trichoderma, as single cultures or in isolate mixtures were tested for their biocontrol efficacy against rubber seedlings inoculated with one of three strains of Rigidoporus lignosus. Biocontrol efficacy of isolates was varied, but not significantly affected by strains of $R$. lignosus. Mixtures of four isolates were significantly $(\mathrm{P}<0.05)$ reduced the disease severity and percentage of root necrotic as compared to mixtures of two isolates as well as single isolates. The highest disease suppression (65\% relative to control) and reduction of inocula on rubber wood sticks (91\% relative to control) was achieved in four isolate mixtures of Trichoderma virens (T1+T4+ T9+ T11).
\end{abstract}

Key words : mycoparasites, Trichoderma virens, Rigidoporus lignosus, hevea rubber

\section{PENDAHULUAN}

Rigidoporus lignosus (Klotzsch) Imazeki sinonim $R$. microporus (Sw.) Overeem dikenal sebagai jamur akar putih (JAP) merupakan jamur Polyporaceae penyebab penyakit akar putih pada tanaman industri, terutama karet (Situmorang, 2004), lada dan ubikayu (Suwandi, 2003). Jamur ini menimbulkan lapuk pada akar dan leher akar sehingga menyebabkan kematian tanaman. JAP diperkirakan menyebabkan kematian 3\% pada perkebunan besar dan 5\% pada perkebunan karet rakyat di Indonesia dengan taksiran nilai kerugian mencapai Rp.300 miliar setiap tahunnya (Situmorang, 2004).

Pengelolaan penyakit akar putih yang selama ini dikembangkan di Indonesia dan kawasan tropika lainnya belum didasarkan atas genetika populasi fungi patogen. Berdasarkan kajian menggunakan marka ketak-sesuaian somatik, populasi lokal $R$. lignosus pada kebun karet terdiri dari beragam genotipe (individu genetik/genet) yang memencar secara klon membentuk teritorial jalinan miselium (Suwandi et al., 2004). Suatu teritorial klon JAP dapat mencakup areal yang cukup luas $\left(2500 \mathrm{~m}^{2}\right)$ dan persisten selama 33 tahun (Suwandi, 2006). Pola pemencaran tersebut menyebabkan patogen ini sukar dikendalikan. Strategi pengendalian penyakit akar putih yang dianjurkan adalah pengurangan inokulum awal dengan pembongkaran tunggul dan penekanan laju infeksi menggunakan fungisida, jamur dan tanaman antagonis (Sitomurang, 2004).
Jamur antagonis dengan modus aksi mikoparasitisme berpotensi dikembangkan sebagai biofungisida karena mampu mengendalikan struktur istirahat patogen yang tidak dapat dilakukan oleh jamur antagonis dengan modus aksi lainnya (Adams, 1990). Selama ini potensi jamur mikoparasit belum dimanfaatkan sepenuhnya sebagai agensia hayati untuk pengendalian penyakit akar putih. Hal ini disebabkan dalam proses seleksi awal, aktivitas mikoparasitisme bukanlah menjadi kriteria utama, tetapi lebih didasarkan kemampuan antagonisme keseluruhan. Pada penelitian ini, seleksi kandidat biokontrol dilakukan dengan metode pra-koloni. Dengan metode ini, hanya jamur yang mampu tumbuh di atas miselium patogen (mampu memarasit miselium patogen) yang akan terpilih (Krauss et al., 1999).

Ketidakmantapan kemanjuran agensia hayati di lapangan merupakan kendala utama pengendalian hayati. Ketidakmantapan kemanjuran ini dapat disebabkan oleh perbedaan kepekaan strain patogen terhadap agensia hayati. Suwandi (2005) menemukan adanya keragaman respon individu genetik JAP terhadap pengkolonian jamur mikoparasit. Sebelumnya, Pudjihardjo (1997) melaporkan adanya perbedaan kepekaan isolat $R$. lignosus dari daerah yang berbeda terhadap isolat Trichoderma spp. Penelitian ini menggunakan pendekatan keragaman genetik patogen untuk pengendalian hayati $R$. lignosus. Keanekaragaman jamur mikoparasit diberdayakan melalui pendekatan kombinasi isolat yang sinergis sehingga dihasilkan agensia biokontrol

\footnotetext{
${ }^{1}$ Jurusan Hama dan Penyakit Tumbuhan, Fakultas Pertanian, Universitas Sriwijaya, Kampus Inderalaya Ogan Ilir Inderalaya 30662 e-mail : suwandi@unsri.ac.id
} 
yang lebih efektif dan mapan terhadap populasi patogen yang beragam genetiknya. Penelitian bertujuan untuk mengevaluasi kemanjuran kombinasi isolat Trichoderma mikoparasit dalam menekan penyakit akar putih yang diinokulasi dengan isolat JAP yang berbeda genetiknya.

\section{METODE PENELITIAN}

Patogen. Strain $R$. lignosus Sbs10 dan Sbl1 diisolasi dari basidiokarp yang tumbuh pada tunggul karet di Sembawa, Sumatera Selatan. Strain Klb31 diisolasi dari basidiokarp pada tunggul kelapa di Balunijuk, Bangka. Masing-masing strain digolongkan ke dalam kelompok kesesuaian miselium yang berbeda, kevirulenan tinggi dan aktivitas ligninolisis tinggi (Suwandi, 2006).

Jamur antagonis. Jamur antagonis diisolasi dari miselium JAP yang terkontaminasi saat isolasi JAP dari Sumatera Selatan dan Bangka. Isolat dipilih berdasarkan kemampuannya mengkoloni miselium JAP (metode pra-koloni). Satu potongan biakan jamur antagonis (ukuran $20 \times 5 \mathrm{~mm}$ ) umur 3 hari ditempatkan pada biakan JAP umur 10 hari yang telah menutupi permukaan MEA (malt extract agar). Dari total 21 jamur antagonis yang dapat tumbuh di atas miselium JAP, dipilih 8 isolat Trichoderma yang berspora baik pada miselium JAP (Tabel 1). Pemilihan isolat tersebut juga didasarkan oleh kesesuaian isolat tersebut, saat dibiakkan bersamasama pada MEA. Berdasarkan ciri morfologi koloni (keberadaan pustula, sel steril pada pustula, perpanjangan konidiofor steril); percabangan konidiofor; bentuk, ukuran, kedudukan dan susunan fialid; bentuk dan ukuran konidium menurut Samuels et al. (2006), seluruh isolat Trichoderma uji (T1, T4, T9, T11, T33, T39, T50 dan T51) diidentifikasi sebagai Trichoderma virens (Miller, Giddens \& Foster) Arx yang merupakan sinonim Gliocladium virens Miller, Giddens \& Foster. Pengamatan mikroskopis menunjukkan bahwa isolat ini digolongkan sebagai mikoparasit karena memarasit miselium JAP dengan cara melakukan penetrasi hifa.

Uji biokontrol. Kemampuan biokontrol Trichoderma mikoparasit diuji berdasarkan penekanan penyakit pada bibit karet yang telah dikoloni oleh strain $R$. lignosus. Pengujian dilaksanakan dengan menggunakan rancangan acak kelompok yang disusun secara faktorial. Faktor pertama yaitu strain $R$. lignosus yang terdiri dari 3 taraf (Sbs10, Sbl1 dan Klb31). Faktor kedua yaitu aplikasi Trichoderma yang terdiri dari 11 taraf (4 taraf isolat tunggal, 4 taraf kombinasi 2 isolat, 2 taraf kombinasi 4 isolat, 1 taraf kontrol). Empat taraf perlakuan isolat tunggal Trichoderma yaitu biakan isolat T1, T9, T33 dan T50. Empat taraf kombinasi dua isolat Trichoderma yaitu campuran biakan isolat T4 dan T9 (T4+T9), T1 dan T11 (T1+T11), T33 dan T39 (T33+T39), dan T50 dan T51 (T50+51). Dua taraf kombinasi empat isolat Trichoderma yaitu campuran biakan T1, T4, T9 dan T11 (T1+T4+T9+T11) serta campuran biakan T33, T39, T50 dan T51 (T33+T39+T50+T51). Pengujian dilakukan dalam 4 ulangan dan setiap ulangan terdiri dari 2 tanaman uji.

Bibit karet uji yang digunakan adalah bibit asal biji dari tanaman klon GT1. Bibit berumur 2 bulan dipangkas bagian ujung akar tunggangnya sehingga tersisa akar tunggang sepanjang $10 \mathrm{~cm}$. Akar lateral dibersihkan dan bagian batang dipangkas sebatas calon mata tunas paling bawah. Bibit selanjutnya ditanam pada pot plastik (volume $350 \mathrm{~mL}$ ) dalam media tanam campuran pasir dan tanah (1:1) yang diotoklaf. Bibit ditumbuhkan selama 1 bulan sampai membentuk daun baru yang berkembang sempurna.

Inokulum patogen disiapkan dengan cara menginokulasi potongan kayu karet ukuran 10 x 5 x $50 \mathrm{~mm}$ dengan biakan JAP dan diinkubasikan selama 2 bulan. Inokulasi patogen dilakukan dengan menanam satu potong inokulum bersinggungan dengan akar tunggang bibit uji.

Masing-masing isolat Trichoderma (T1, T9, T33 dan T50) diperbanyak secara terpisah menggunakan media campuran tepung jagung dan serbuk gergaji dengan perbandingan berat 1:1 selama 12 hari. Biakan selanjutnya dikeringanginkan selama 3 hari pada suhu ruang. Pada perlakuan kombinasi dua dan empat isolat, biakan masing-masing isolat tungal dicampur satu sama lain sesuai dengan taraf perlakuan tersebut. Pencampuran dilakukan dalam perbandingan berat yang sama (perbandingan 1:1 untuk campuran 2 isolat dan 1:1:1:1 untuk campuran 4 isolat). Sebelum diaplikasi, kandungan total propagul hidup Trichoderma pada biakan tunggal dan campuran biakan dihitung dengan melalui metode pengenceran berseri yang diikuti dengan pembiakan pada MEA. Aplikasi Trichoderma dilakukan setelah 14 hari 
inokulasi JAP, yaitu setelah akar tunggang dikoloni oleh rhizomorf JAP. Setiap biakan isolat atau campuran biakan isolat Trichoderma dibenamkan sehingga mengenai akar tunggang tanaman uji dengan takaran total setara $1 \times 10^{6}$ unit pembentuk koloni (upk)/g medium tanam (berat kering).

Dua bulan setelah inokulasi JAP, tanaman uji dibongkar untuk mengamati keparahan penyakit dan persentase nekrosis akar tunggang. Keparahan penyakit diukur berdasarkan 9 skala menurut Nandris et al. (1987). Persentase nekrosis akar tunggang ditentukan dengan membandingkan panjang akar yang mengalami nekrosis dengan total panjang akar tunggang. Setiap minggu setelah inokulasi JAP, tinggi tanaman uji diukur untuk mengetahui respon pertumbuhan bibit karet setelah dilakukan aplikasi dengan Trichoderma.

Seluruh akar tunggang uji dipotong dan dibalut dengan kertas tisu yang dibasahkan dengan air steril yang mengandung benomil $100 \mathrm{mg} / \mathrm{L}$ dan streptomisin $100 \mathrm{mg} / \mathrm{L}$ dan dimasukkan dalam kantong plastik. Setelah inkubasi selama 7 hari, pertumbuhan miselium JAP dari akar tunggang diamati untuk menentukan mortalitas miselium pada akar tunggang. Sumber inokulum JAP pada potongan kayu juga diperlakukan dengan cara yang sama, untuk menentukan mortalitas miselium pada inokulum.

Pengaruh strain JAP, perlakuan Trichoderma dan interaksinya dianalisis secara statistik menggunakan proc glm pada SAS Systems for Windows versi 9.0. Jika salah satu faktor berpengaruh signifikan $(\mathrm{P}<0.05)$, maka perbedaan rata-rata taraf faktor dibandingkan dengan menggunakan WallerDuncan K-ratio $t$ Test. Perbedaan pengaruh antara kelompok perlakuan (isolat tunggal, kombinasi 2 dan 4 isolat) dibandingkan menggunakan uji ortogonal kontras.

\section{HASIL DAN PEMBAHASAN}

Analisis ragam menunjukkan bahwa perlakuan Trichoderma mikoparasit berpengaruh nyata $(\mathrm{P}<$ 0.05) terhadap keparahan penyakit, nekrosis akar, mortalitas miselium dalam potongan kayu dan mortalitas miselium pada akar bibit karet, tetapi tidak berpengaruh nyata terhadap pertumbuhan bibit. Meskipun secara deskriptif ditemukan keragaman pertumbuhan parasit Trichoderma pada koloni $R$. lignosus pada cawan Petri (Tabel 1), secara statistik tidak ditemukan interaksi secara nyata antara strain JAP dengan aplikasi Trichoderma (Tabel 2). Hasil ini mengindikasikan bahwa secara in planta kemanjuran penekanan penyakit oleh Trichoderma mikoparasit tidak dipengaruhi oleh isolat patogen sasaran. Hasil ini berbeda dengan hasil pengujian sebelumnya yang menunjukkan adanya diskriminasi strain Trichoderma mikoparasit terhadap strain $R$. lignosus. Pertumbuhan parasit miselium Trichoderma pada miselium $R$. lignosus secara in vitro dipengaruhi oleh isolat $R$. lignosus (Suwandi, 2005). Diskriminasi strain Trichoderma spp. juga telah dilaporkan pada patogen kakao yaitu Phytophthora palmivora, Crinipelis perniciosa dan Moniliophthora roreri (Krauss et al., 1999) dan patogen antraknosa buah pisang, Colletotrichum musae (Krauss et al., 2001). Tidak adanya tanggap nyata isolat JAP diduga disebabkan oleh tingginya keragaman percobaan (koefisien keragaman $=21,3 \%$ ) yang dapat diminimalisasi dengan menambah ulangan. Diskriminasi strain dapat tetap berpotensi mempengaruhi kemanjuran agensia biokontrol ini di lapangan, karena pengaruh kerumitan sifat biologi dan kimia tanah terhadap interaksi antagonis dan patogen.

Analisis beda rata-rata antar-kelompok menggunakan metode ortogonal kontras menunjukkan bahwa keparahan dan nekrosis akar pada tanaman diaplikasi kombinasi 4 isolat Trichoderma nyata lebih rendah dibandingkan kombinasi 2 isolat dan isolat tunggal (Tabel 3). Dibandingkan dengan perlakuan lainnya, kombinasi 4 isolat $\mathrm{T} 1+\mathrm{T} 4+\mathrm{T} 9+\mathrm{T} 11$ dan T33+T39+T50+T51 dapat menekan rata-rata 65 dan 52\% keparahan penyakit (Gambar 1). Perlakuan kombinasi isolat $\mathrm{T} 1+\mathrm{T} 4+\mathrm{T} 9+\mathrm{T} 11$ lebih unggul dalam menekan sumber inokulum (miselium) dalam potongan kayu dengan penekanan relatif sebesar 91\%. Jika diaplikasikan sebagai isolat tunggal, masingmasing isolat tersebut dapat mematikan miselium pada akar tunggang, tetapi kurang efektif terhadap miselium dalam potongan kayu (Tabel 4).

Hasil penelitian ini membuktikan kombinasi 4 isolat Trichoderma mikoparasit lebih unggul dalam menekan penyakit dan mengurangi inokulum dibandingkan penggunaan kombinasi 2 isolat dan isolat tunggal. Keunggulan biokontrol kombinasi isolat Trichoderma juga telah dilaporkan terhadap patogen antraknosa buah pisang, Colletotrichum 
Tabel 1. Ciri pertumbuhan parasit Trichoderma virens pada koloni Rigidoporus lignosus

\begin{tabular}{|c|c|c|c|c|c|}
\hline \multirow{2}{*}{$\begin{array}{c}\text { Isolat Trichoderma } \\
\text { virens }\end{array}$} & \multirow{2}{*}{$\begin{array}{c}\text { Strain } \\
\text { Rigidoporus } \\
\text { lignosus }\end{array}$} & \multicolumn{3}{|c|}{ Pensporaan pada miselium JAP } & \multirow{2}{*}{$\begin{array}{c}\text { Lisis pada } \\
\text { miselium } R \\
\text { lignosus }^{4}\end{array}$} \\
\hline & & Kecepatan $^{1}$ & Ketebalan $^{2}$ & Penyebaran $^{3}$ & \\
\hline \multirow{3}{*}{$\mathrm{T} 1$} & Sbs10 & +++ & + & + & + \\
\hline & Sbl1 & +++ & + & + & + \\
\hline & Klb31 & +++ & + & ++ & + \\
\hline \multirow{3}{*}{$\mathrm{T} 4$} & Sbs10 & +++ & ++ & + & + \\
\hline & Sbl1 & +++ & ++ & + & - \\
\hline & Klb31 & +++ & +++ & ++ & + \\
\hline \multirow{3}{*}{ T9 } & Sbs10 & +++ & +++ & ++ & - \\
\hline & Sbl1 & +++ & +++ & + & + \\
\hline & Klb31 & +++ & +++ & ++ & + \\
\hline \multirow{3}{*}{$\mathrm{T} 11$} & Sbs10 & +++ & + & + & + \\
\hline & Sbl1 & +++ & +++ & + & + \\
\hline & Klb31 & +++ & +++ & ++ & + \\
\hline \multirow{3}{*}{ T33 } & Sbs10 & +++ & +++ & ++ & - \\
\hline & Sbl1 & +++ & +++ & ++ & + \\
\hline & Klb31 & +++ & +++ & + & + \\
\hline \multirow{3}{*}{ Т39 } & Sbs10 & ++++ & +++ & ++ & - \\
\hline & Sbl1 & +++ & +++ & ++ & + \\
\hline & Klb31 & ++++ & +++ & ++ & - \\
\hline \multirow{3}{*}{ T50 } & Sbs10 & +++ & + & ++ & + \\
\hline & Sbl1 & +++ & +++ & ++ & + \\
\hline & Klb31 & +++ & +++ & ++ & + \\
\hline \multirow{3}{*}{ T51 } & Sbs10 & +++ & +++ & ++ & + \\
\hline & Sbl1 & +++ & +++ & + & + \\
\hline & Klb31 & +++ & +++ & ++ & + \\
\hline
\end{tabular}

${ }^{1}$ Kecepatan pensporaan Trichoderma di atas miselium $R$. lignosus, $+++=$ cepat (pensporaan terjadi setelah 6 hari penanaman inokulum), $++++=$ sangat cepat (pensporaan terjadi $<6$ hari dari penanaman inokulum).

${ }^{2}$ Ketebalan pensporaan Trichoderma di atas miselium $R$. lignosus, $+=$ tipis, $++=$ sedang, $+++=$ konidium tebal dan menumpuk.

${ }^{3}$ Penyebaran spora Trichoderma di atas miselium $R$. lignosus, $+=$ menyebar tidak merata, $++=$ menyebar merata.

${ }^{4}$ Lisis atau penipisan miselium $R$. lignosus yang dikoloni Trichoderma, - = tidak ada lisis, $+=$ terjadi lisis. 
Tabel 2. Nilai propabilitas (P) analisis ragam pengaruh perlakuan pengobatan menggunakan Trichoderma virens terhadap penyakit akar putih, mortalitas miselium Rigidoporus lignosus dan pertumbuhan bibit karet

\begin{tabular}{|c|c|c|c|c|c|}
\hline \multirow{2}{*}{$\begin{array}{l}\text { Sumber } \\
\text { Keragaman }\end{array}$} & \multicolumn{5}{|c|}{ Probabilitas (P) } \\
\hline & $\begin{array}{l}\text { Keparahan } \\
\text { penyakit }\end{array}$ & $\begin{array}{c}\text { Nekrosis akar } \\
\text { (\%) }\end{array}$ & $\begin{array}{c}\text { Mortalitas } \\
\text { inokulum (\%) }\end{array}$ & $\begin{array}{c}\text { Mortalitas } \\
\text { miselium (\%) }\end{array}$ & $\begin{array}{l}\text { Pertambahan tinggi } \\
\text { tanaman (mm/minggu) }\end{array}$ \\
\hline Strain JAP & 0,5954 & 0,3032 & 0,5876 & 0,2257 & 0,5445 \\
\hline Trichoderma & $<, 0001^{*}$ & $<, 0001^{*}$ & $0,0271^{*}$ & 0,0023* & 0,9733 \\
\hline $\begin{array}{l}\text { Strain JAP } \mathrm{x} \\
\text { Trichoderma }\end{array}$ & 0,8736 & 0,8838 & 0,9860 & 0,1633 & 0,8430 \\
\hline
\end{tabular}

*Signifikan pada $\mathrm{P}<0.05$

Tabel 3. Nilai probabilitas (P) analisis ortogonal kontras pengaruh jumlah isolat Trichoderma virens terhadap penyakit akar putih, mortalitas miselium Rigidoporus lignosus dan pertumbuhan bibit karet

\begin{tabular}{|c|c|c|c|c|c|}
\hline \multirow[b]{2}{*}{ Kontras } & \multicolumn{5}{|c|}{ Probabilitas (P) } \\
\hline & $\begin{array}{l}\text { Keparahan } \\
\text { penyakit }\end{array}$ & $\begin{array}{l}\text { Nekrosis } \\
\text { akar (\%) }\end{array}$ & $\begin{array}{l}\text { Mortalitas } \\
\text { miselium pada } \\
\text { kayu (\%) }\end{array}$ & $\begin{array}{l}\text { Mortalitas } \\
\text { miselium pada } \\
\text { akar (\%) }\end{array}$ & $\begin{array}{c}\text { Pertambahan tinggi } \\
\text { tanaman } \\
\text { (mm/minggu })\end{array}$ \\
\hline $\begin{array}{l}\text { Kontrol vs } \\
\text { Trichoderma }\end{array}$ & $<, 0001^{*}$ & $<, 0001^{*}$ & 0,1262 & 0,2662 & 0,7109 \\
\hline $\begin{array}{l}\text { Isolat tungal vs } \\
\text { Kombinasi } 2 \text { isolat }\end{array}$ & 0,3124 & 0,1059 & 0,5295 & 0,1519 & 0,2293 \\
\hline $\begin{array}{l}\text { Kombinasi } 4 \text { isolat } \\
\text { vs (Isolat tungal }+ \\
\text { Kombinasi } 2 \text { isolat) }\end{array}$ & $<, 0001^{*}$ & $0,0002 *$ & 0,3492 & 0,1847 & 0,3875 \\
\hline
\end{tabular}

*Signifikan pada $\mathrm{P}<0.05$ 
Tabel 4. Pengaruh perlakuan pengobatan menggunakan isolat tunggal dan kombinasi isolat Trichoderma virens terhadap penyakit akar putih, mortalitas miselium Rigidoporus lignosus dan pertumbuhan bibit karet

\begin{tabular}{|c|c|c|c|c|c|c|c|c|c|c|}
\hline \multirow{2}{*}{$\begin{array}{l}\text { Aplikasi mikoparasit } \\
\text { Isolat tunggal }\end{array}$} & \multicolumn{2}{|c|}{$\begin{array}{c}\text { Keparahan } \\
\text { penyakit }^{1}\end{array}$} & \multicolumn{2}{|c|}{$\begin{array}{l}\text { Nekrosis akar } \\
\text { tunggang (\%) }\end{array}$} & \multicolumn{2}{|c|}{$\begin{array}{c}\text { Mortalitas } \\
\text { miselium } \\
\text { dalam kayu } \\
(\%)\end{array}$} & \multicolumn{2}{|c|}{$\begin{array}{l}\text { Mortalitas } \\
\text { miselium pada } \\
\text { akar (\%) }\end{array}$} & \multicolumn{2}{|c|}{$\begin{array}{l}\text { Pertambahan } \\
\text { tinggi tanaman } \\
\text { (mm/minggu) }\end{array}$} \\
\hline & & & & & & & & & & \\
\hline $\mathrm{T} 1$ & 4,1 & $c^{2}$ & 31,7 & $b^{2}$ & 25,0 & $a b^{2}$ & 70,8 & $a^{2}$ & 4,0 & $a^{2}$ \\
\hline T9 & 6,0 & $a b$ & 54,1 & $\mathrm{a}$ & 16,7 & $a b$ & 54,2 & abcd & 4,6 & a \\
\hline T33 & 3,7 & $\mathrm{~cd}$ & 28,4 & b & 4,2 & b & 25,0 & d & 4,4 & a \\
\hline $\mathrm{T} 50$ & 6,4 & $\mathrm{a}$ & 53,7 & $\mathrm{a}$ & 29,2 & $a b$ & 79,2 & $\mathrm{a}$ & 3,9 & a \\
\hline \multicolumn{11}{|l|}{ Kombinasi 2 isolat } \\
\hline $\mathrm{T} 4+\mathrm{T} 9$ & 4,1 & c & 23,4 & $\mathrm{~b}$ & 4,2 & $\mathrm{~b}$ & 33,3 & $\mathrm{~cd}$ & 3,7 & a \\
\hline $\mathrm{T} 1+\mathrm{T} 11$ & 6,0 & $a b$ & 53,6 & $\mathrm{a}$ & 8,3 & b & 33,3 & $\mathrm{~cd}$ & 3,7 & $\mathrm{a}$ \\
\hline T33+T39 & 4,5 & bc & 28,3 & $\mathrm{~b}$ & 16,7 & $a b$ & 62,5 & $\mathrm{ab}$ & 3,5 & a \\
\hline $\mathrm{T} 50+\mathrm{T} 51$ & 3,5 & $\mathrm{~cd}$ & 21,8 & b & 29,2 & $a b$ & 54,2 & $\mathrm{abc}$ & 3,8 & $\mathrm{a}$ \\
\hline \multicolumn{11}{|l|}{ Kombinasi 4 isolat } \\
\hline$\overline{\mathrm{T} 1+\mathrm{T} 4+\mathrm{T} 9+\mathrm{T} 11}$ & 2,6 & d & 13,2 & $\mathrm{~b}$ & 45,8 & $\mathrm{a}$ & 62,5 & abc & 3,5 & $\mathrm{a}$ \\
\hline T33+T39+T50+T51 & 3,5 & $\mathrm{~cd}$ & 17,4 & $\mathrm{~b}$ & 4,2 & $\mathrm{~b}$ & 25,0 & $\mathrm{~d}$ & 3,5 & $\mathrm{a}$ \\
\hline Kontrol & 7,3 & $\mathrm{a}$ & 75,0 & $\mathrm{a}$ & 4,2 & b & 33,3 & bcd & 3,6 & $\mathrm{a}$ \\
\hline
\end{tabular}

${ }^{1}$ Keparahan penyakit berdasarkan skala 0-9 (Nandris et al., 1987); 0 = tanaman sehat; 9 = tanaman mati

${ }^{2}$ Nilai yang diikuti oleh huruf sama adalah tidak berbeda signifikan $(\mathrm{P}<0.05)$ berdasarkan Waller-Duncan $\mathrm{K}$ ratio $t$ Test

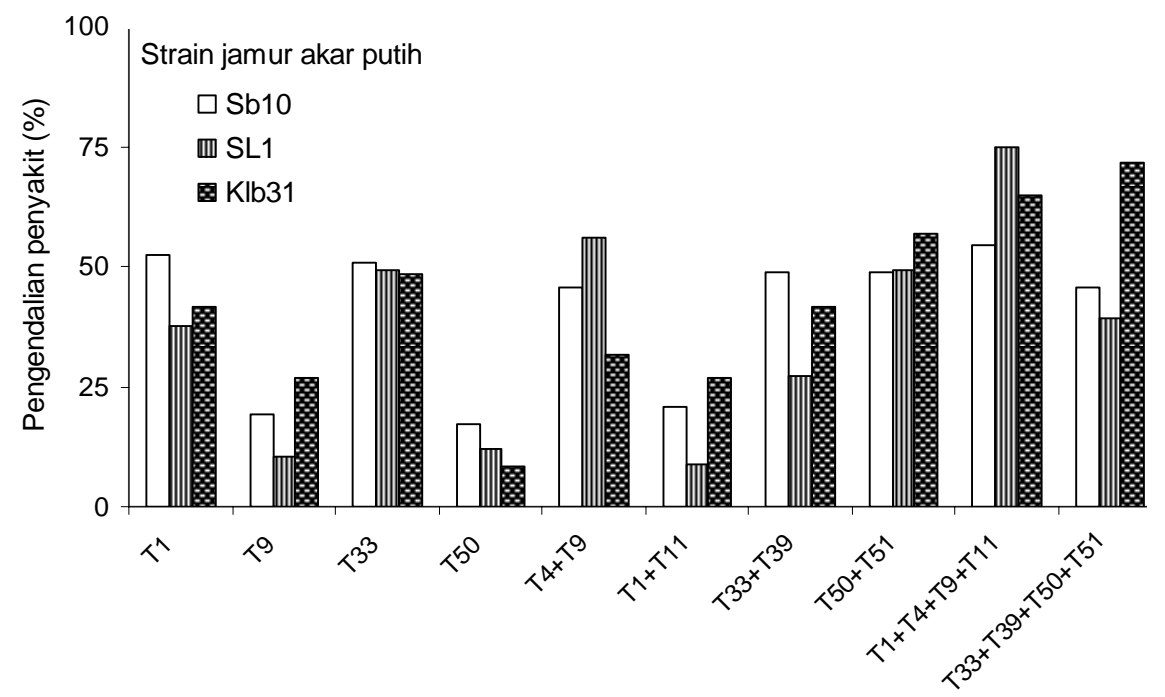

Perlakuan isolat tunggal atau kombinasi isolat Trichoderma virens

Gambar 1. Penekanan keparahan penyakit akar putih (nilai relatif terhadap kontrol) pada perlakuan pengobatan menggunakan isolat tunggal (T1, T9, T33 dan T50), kombinasi dua isolat (T4+T9, T1+T11, T33+T39 dan $\mathrm{T} 50+\mathrm{T} 51$ ) serta kombinasi empat isolat Trichoderma virens (T1+T4+T9+T11 dan T33+T39+T50+T51) 
musae (Krauss et al., 2001) dan Rosselinia spp. penyebab lapuk akar kakao (Garcia et al., 2003).

Meningkatnya penekanan penyakit pada kombinasi isolat dapat disebabkan oleh efek sinergis perpaduan isolat yang mengurangi dampak diskriminasi strain, baik yang disebabkan oleh keragaman genetik patogen maupun keragaman lingkungan tanah. Melalui sinergisme perpaduan isolat yang serasi, kelemahan aksi antagonis suatu isolat akan diganti oleh isolat lainnya. Seluruh isolat Trichoderma uji pada penelitian ini diidentifikasi sebagai $T$. virens. Jamur antagonis ini telah dikenal sejak lama sebagai sebagai agensia biokontrol yang beraksi melalui poduksi antibiotik gliovirin dan gliotoksin (Howell, 1999), pemarasit dengan memproduksi enzim hidrolisis seperti 1,6- $\beta$ glukanase (Djonovic et al., 2006), kompetisi terhadap hara Fe dengan mensekresi siderofor (Wilhite et al., 2001) serta pengimbasan ketahanan (Viterbo et al., 2005). Pada penelitian ini dominasi masing-masing mekanisme penekanan penyakit belum dapat dikaji secara mendalam. Pengkolonian pada miselium JAP dengan cepat yang diikuti dengan lisis, dapat merupakan petunjuk parasitisme lebih dominan bekerja dalam mekanisme penekanan penyakit oleh isolat Trichoderma.

Ekspresi gen penyandi enzim hidrolisis merupakan faktor penentu parasitisme Trichoderma virens (Mendoza-Mendoza et al., 2003). Berat molekul 1,6- $\beta$ glukanase yang disekresi suatu isolat Trichoderma bervariasi tergantung dari isolat Trichoderma dan jenis patogen sasaran (Inglis \& Kawchuk, 2002). Dengan demikian, semakin banyak gabungan isolat Trichoderma yang digunakan, maka produksi enzim hidrolisis akan menjadi lebih beragam. Keragaman enzim penghancur dinding sel ini dapat berguna dalam mengatasi keragaman komposisi dinding sel patogen yang pada akhirnya dapat meningkatkan kemanjuran penekanan penyakit.

Pada penelitian ini penekanan penyakit oleh suatu kombinasi isolat menjadi beragam dan cenderung tidak berhubungan dengan kemampuan individu isolat. Kesesuaian isolat diduga berperanan penting dalam peningkatan kemanjuran. Dengan demikian, faktor kesesuaian isolat merupakan kriteria yang perlu dipertimbangkan dalam pemilihan awal kombinasi isolat unggul. Pada penelitian ini, kesesuaian antar isolat Trichoderma diuji berdasarkan pengamatan visual terhadap lisis dan pertumbuhan abnormal dari interaksi koloni pada media agar. Metode pengujian lain, misalnya dengan penggunaan pewarna sebagai indikator aktivitas enzim fenoloksidase sebagai tanggap dari ketidaksesuaian isolat dapat dikaji lebih lanjut.

\section{DAFTAR PUSTAKA}

Adams, P.B. 1990. The Potential of mycoparasites for biological control of plant diseases. Annu. Rev. Phytopathol. 28:59-72.

Djonovic, S., M.J. Pozo, \& C.M. Kenerley. 2006 Tvbgn3, a ß-1,6-glucanase from the biocontrol fungus Trichoderma virens, is involved in mycoparasitism and control of Pythium ultimum. Appl. Environ. Microbiol. 72(12):7661-7670.

Garcia, R.A.M., G.M.T. Hoopen, D.C.J. Kass, V.A.S. Garita, \& U. Krauss. 2003. Evaluation of mycoparasites as biocontrol agents of Rosellinia root rot in cocoa. Biological Control 27(2):210227.

Howell, C.R. 1999. Selective isolation from soil and separation in vitro of $\mathrm{P}$ and $\mathrm{Q}$ strains of Trichoderma virens with differential media. Mycologia 91(6): 930-934.

Inglis, G.D. \& L.M. Kawchuk. 2002. Comparative degradation of oomycete, ascomycete, and basidiomycete cell walls by mycoparasitic and biocontrol fungi. Can. J. Microbiol. 48:60-70.

Krauss, U., P. Matthews, R. Bidwell, M. Hocart, \& F. Anthony. 2001. Strain discrimination by fungal antagonists of Colletotrichum musae: implications for biocontrol of crown rot of banana. Mycol. Res. 105:67-76.

Krauss, U., W. Soberanis, \& P. Matthews. 1999. The use antagonist mixtures in biocontrol. In Krauss, U. \& P. Hebbar, eds. Workshop Manual of Research Methodology for the Biological Control of Plant Disease with Special Reference to Fungal Diseases of Cocoa. Costa Rica, 28 June- 4 July, 1999. 
Mendoza-Mendoza, A., M.J. Pozo, D. Grzegorski, P. Martinez, J.M. Garcia, V. Olmedo-Monfil, C. Cortes, C. Kenerley, \& A. Herrera-Estrella. 2003. Enhanced biocontrol activity of Trichoderma through inactivation of a mitogenactivated protein kinase. Proc. Natl. Acad. Sci. USA 100(26): 15965-15970.

Nandris, D., M. Nicole, \& J.P. Geiger. 1987. Variation in virulence among Rigidoporus lignosus and Phellinus noxius isolates from West Africa. Eur. J. For. Path. 17: 271-281.

Pudjihardjo, B. 1997. Antagonisme Trichoderma dari Beberapa Daerah Terhadap Jamur Akar Putih pada Karet Hevea. Tesis. Program Pascasarjana, Univ. Gadjah Mada, Yogyakarta. (Tidak dipublikasikan).

Samuels, G.J., P. Chaverri, D.F. Farr, \& E.B. McCray. 2006. Trichoderma Online, Systematic Botany \& Mycology Laboratory, ARS, USDA. Retrieved February 5, 2006, from http://nt.arsgrin.gov/taxadescriptions/keys/TrichodermaInd ex.cfm.

Sitomurang, A. 2004. Status dan manajemen pengendalian penyakit akar putih di perkebunan karet. Hlm.66-86 dalam: Sitomurang, A., A. Budiman, H. Suryaningtyas, Thomas, M. Lasminingsih, \& A. Gunawan, eds. Prosiding Pertemuan Teknis Strategi Pengelolaan Penyakit Tanaman Karet untuk Mempertahankan Potensi Produksi Mendukung Industri Perkaretan Indonesia Tahun 2020. Palembang, 6-7 Oktober 2004.
Suwandi, H. Hamidson, \& S. Naito, 2004. Distribution of Rigidoporus lignosus genotypes in a rubber plantation as revealed by somatic compatibility. Mycoscience 45(1):72-75.

Suwandi. 2003. Penyakit akar putih pada tanaman lada yang disebabkan Rigidoporus lignosus. Hal.366-370 dalam: Purwantara, A., D. Sitepu, I. Mustika, K. Mulya, M.S. Sudjono, M. Machmud, S.H. Hidayat, Supriadi, \& Widodo, eds. Prosiding Kongres XVII dan Seminar Nasional Perhimpunan Fitopatologi Indonesia. Bandung, 6-8 Agustus 2003.

Suwandi. 2005. Strain discrimination by fungal antagonists of Rigidoporus microporus. Presented paper at International Conference of Crops Security. Malang, Indonesia, September 20-22, 2005.

Suwandi. 2006. Mode of dispersal and variation in population of white root fungus Rigidoporus microporus as revealed by mycelial incompatibility. Presented paper at International Workshop on White Root Disease on Hevea Rubber. Getas, Indonesia, $28^{\text {th }}$ November 2006.

Viterbo, A., M. Harel, B. A. Horwitz, I. Chet, \& P.K. Mukherjee. 2005. Trichoderma mitogenactivated protein kinase signaling is involved in induction of plant systemic resistance. Appl. Environ. Microbiol. 71(10): 6241-6246.

Wilhite, S.E., R.D. Lumsden, \& D.C. Straney. 2001. Peptide synthetase gene in Trichoderma virens. Appl. Environ. Microbiol. 67(11):5055-5062. 